\title{
Job Mismatch and Overeducation among Graduates in Malaysia
}

\author{
Asnida Shahidan*, Russayani Ismail, Siti Norliza Jumali \\ Department of Economics and Agribusiness, School of Economics, Finance and Banking, Universiti Utara \\ Malaysia
}

\begin{abstract}
The supply of young graduates entering Malaysia labour market due to the expansion in higher education undergone a sharp increase. A consequence of this is an increase in the number of individuals who are unemployed and doing jobs with low income and depressing job environment. In other words, they are doing jobs that do not commensurate to their level of educational qualifications or referred to as overeducation. By using a Job Analyst Method, which is one of the frequent methods used to measure overeducation and data from Graduate Tracer Study (GTS) published by the Ministry of Education Malaysia from 2012 - 2017, this paper provides a descriptive analysis on the extent of overeducation among graduates. The result highlights that the percentage of overeducated graduates keep on increasing, and the majority of them engaged in the labour market as clerks and sales workers.
\end{abstract}

Keywords: Overeducation, Job Analyst Method, Graduates, Job Mismatch, Education

JEL Classification: A23, I24, I25, J01

Paper Type: General Review

\section{INTRODUCTION}

Investment in human capital, specifically at the tertiary level is imperative as more skilled, knowledgeable and innovative labours are needed. Due to this, Malaysia has experienced rapid development of tertiary education industry after the introduction of Private Higher Education Institutions (HEls) Act in 1996 and the liberalization of higher education. Following this development, many public and private higher institutions have been established, and a lot of public funds have been invested for the purpose of raising the quality of education, particularly higher education at the international level. By 2018, Malaysia had 20 public universities, 96 private university, 497 private colleges and 11 private branch campus of a foreign university. Due to the high demand for higher education, the number of student enrollments rose by 76.8 percent from 698,156 in 2003

\footnotetext{
*Corresponding author: E-mail: asnida@uum.edu.my, Phone: +6049286796
} 
to $1,234,326$ in 2018 . The number of graduates also increased by around 7 percent from 244,487 to 261,236 during the same period (Statistik Pendidikan Tinggi, 2003; 2018).

The fast expansion of higher education has contributed to the increase in the number of graduates in the labour market. Despite the positive outcome, however, graduates faced difficulty placing themselves in the job market. The increasing number of graduates (Figueiredo et al., 2017) and economic conditions (Summerfield \& Theodossiou, 2017) has put pressure on graduates' employability and job allocation, resulting in inefficient use of human capital endowment. Consequently, it does not only contribute to the rise of unemployment among youth in the market but relatively shows there are some people doing jobs that are less secured with low income and depressing job environment. In other words, they are doing jobs that do not commensurate with their level of educational qualifications or known as overeducation (Garcia-Espejo \& Ibáñez, 2006; Rahona-López \& Pérez-Esparrells, 2013; Gajderowicz, Grotkowski \& Wincenciak, 2014). For example, an employee with a university degree doing work that only requires the Malaysian Certificate of Education (MCE) or better known as Sijil Pelajaran Malaysia (SPM), or such as software engineer accepting a position as clerk assistant.

Generally, the phenomenon of overeducation in Malaysia has initially been studied since the 1980s when Zainizam (2012) reported that Abdul Aziz et al. (1987) began to raise this issue and found that six percent of post-secondary educated workers and 12 percent of highly educated did not have a job that commensurates with their qualifications. Later on, it has been reported that the total graduates who were in this non-graduate job contributed around 30 to 41 percent or one-third of the employed graduate (Ishak, Rahmah \& Robiah, 2008; Lim, 2013; Zainizam \& Battu, 2013). However, issues on overeducation have not received great attention in Malaysia. As overeducation will bring inefficiency in the labour market and pose detrimental effects to individuals, firm and country as a whole such as lowering individual income levels (Sicherman, 1991; Zainizam et al., 2014), happiness (Lim, 2013), health, well-being and life satisfaction (Piper, 2015; Friedland \& Price, 2003), influence job satisfaction (Ortiz, 2010) and a signal of productivity loss (Boll, Leppin \& Schomann, 2016), it is therefore timely to examine the extent of overeducation among Malaysian graduates by providing a descriptive analysis using a Job Analyst Method of measurement and data from the Graduate Tracer Study (GTS). Since all previous studies in Malaysia only concentrated on self-perceived method, for instance, a study that has been carried out by Zainizam (2017, 2012), Lim (2013) and Zulkifli and Hazrul Izwan (2013), this study is expected to contribute to the literature through the use of a Job Analyst Method measurement.

For the purpose of this paper, the discussion pertaining to overeducation will be referred to vertical mismatch of skill, i.e. by comparing the level of education attained and the level of education required by the occupation as defined by the International Labour of Organization (ILO). Furthermore, the concept of mismatch and overeducation are referred to as the same as mentioned by Halaby (1994), and they are interchangeably used. Consistent with many previous studies, a mismatch concept being discussed here will focus on the educational aspects alone and will ignore the skills part. The reason for this is because measuring skill often involves a proxy such as educational attainment (ILO, 2013). If this proxy is used to represent skill mismatch, then it has no difference between skills and educational mismatch. It is also important to note that this paper does not take into account the difference of traits between graduates in each classification of jobs.

Following the introduction in section one, section two highlights the pertinent issues with regard to the definition and the concept of mismatch and overeducation in section 2.1, followed by measurement of overeducation in section 2.2. Section three discusses the data, methodology and results. Finally, section four concludes the paper. 


\section{LITERATURE REVIEW}

The individual is labelled as overeducated if his/her level of education attained is higher than the level of education required for a particular occupation. This situation indicates that an individual's human capital endowment in terms of knowledge and skills is underutilized in the labour market and therefore demonstrates that highly educated human resources are not efficiently allocated to their occupation. Issue of overeducation was first studied by Freeman in 1976 in the United States. This macro-level study found that many of the graduates in the labour force do not work in occupations that match their educational qualifications. Subsequently, the study continued by Rumberger and Duncan and Hoffman in 1981 studies that focus on the micro-level. Although their scopes of study differ, the findings from both studies showed that overeducation incidence increased in the United States during the 1970s and 1980s (Kuchel, 2011).

Due to rapid expansion of higher education, overeducation issues have extensively been examined until now, specifically in developed countries such as in Australia (Linsley, 2005; Voon \& Miller, 2005), Canada (Frenette, 2004; Wald, 2005) and the European Union (Tarvid, 2013). However, studies are more concentrated in European countries such as the United Kingdom (UK), Italy, Switzerland, Germany, Spain and the Netherlands. In Developing Countries, to our knowledge, there are only a few studies that have been carried out. These include Mexico (Quinn \& Rubb, 2006), Pakistan (Abbas, 2008; Farooq, 2011), China (Li, Morgan \& Ding, 2008; Yang \& Mayston, 2012), Malaysia (Zainizam, 2012, 2013, 2014, 2017; Lim, 2013; Zainizam \& Battu, 2013; Zulkifly \& Hazrul Izwan, 2013) and a comparative study between the State of Mexico, India, the Philippines and Thailand (Mehta, Felipe, Quis \& Camingue, 2011).

\subsection{Definition and Concept of Mismatch and Overeducation}

The International Labour Organization (ILO) classifies job mismatch into two types, namely (1) a mismatch between demand and supply of skills based on a comparison of education of working and unemployed people, and (2) a mismatch of skills by comparing education attained and education required by the occupation. In general, a job-education mismatch can be categorized into vertical mismatch and horizontal mismatch. Instead of undereducation, overeducation is another type of vertical imbalance between education attained, and education required. It is a condition where the level of the individual's actual educational qualifications higher than the level of educational qualifications required for the occupation (Büchel \& Pollmann-Schult, 2004).

In the field of economics, management, sociology and psychology, overeducation terminology is often used interchangeably with overqualification (Vaisey, 2006), underutilization (Blenkinsopp \& Scurry, 2011), underemployment (Feldman, 1996; McKeeRyan \& Harvey, 2011) and job or qualification mismatch (Frei \& Sousa-Poza, 2012). Meanwhile, a horizontal mismatch refers to a gap between disciplines studied in higher institution and the scope of tasks performed in a workplace (Wolbers, 2003; Robst, 2007, 2008). Although there are differences between these two types of mismatch, both gaps describe inefficiency in human capital used.

There are different views on the concept of job-educational mismatch and overeducation. Halaby (1994) categorized these two concepts as equal. Whereas, Barcena-Martin, Budria and Egido (2011) tend to disagree as they considered that the discussion of overeducation often ignore the skill aspects possessed by individuals but rather focus on the educational part. This opinion is in line with Allen and De Weert (2007) who pointed out that the scope of mismatch is broader than the overeducation when it 
takes into account the skill aspects together with the educational qualifications in performing work.

For the purpose of this paper, the discussion pertaining to overeducation will be referred to type 2 (a mismatch of skills by comparing education attained and education required by the occupation) as defined by ILO and as same as the concept that mentioned by Halaby (1994) and that they are interchangeably used.

\subsection{Overeducation Measurement}

Overeducation measurement is done by comparing the individual's actual education and the education required by work. Normally, to measure the actual education level is easier than the required one. Thus, there are three main methods frequently used in literature to measure the education level required, namely (1) Job Analyst Method; (2) Workers SelfAssessment; and (3) Realized Match. In other words, these methods, also known as the objective, subjective and empirical or statistic measurement. There are no specific criteria in selecting the best method and which one should be used (Battu, Belfield \& Sloane, 2000; Bla'zquez \& Budrı'a, 2012) because it depends on the availability of data (Boudarbat and Chernoff, 2012) and limitations of the study (Farooq, 2011).

The objective method measures skill and educational level required based on classification done by professional job analyst. This job classification determined by the Dictionary of Occupational Titles in the International Standard Classification of occupation (ISCO). Basically, it reports different types of skills and education optimally required for each occupation category. The individual categorized as overeducated (undereducated) if their education level more (less) than the level of education required in particular work according to this dictionary. Meanwhile, a match level applicable to workers who owned educational level as same as the level of education required.

A self-assessment method also known as a subjective measurement involves giving questionnaires to the respondents, and their response will be based on the valuation of the education level that most relevant to their current employment (Allen \& Van der Velden, 2001; Wald, 2005). In details, Groot and Maassen van den Brink (2000) categorized responses given into two types. First, it involves a direct report on the rate of skills used in their occupations. From the questions asked, they will answer either they are overeducated or not based on their perception and understanding of the work done. Second, respondents need to inform the minimum level of education required for their job. Then, a comparison is made between the minimum level of education needed and their actual education attained.

The common questions being asked to the respondents for this method, such as "what is the minimum level of education needed for this job?" (McGuinness, 2003). Through this method, if respondents choose a lower level of education than their actual education as their answer, then they are labelled as overeducated. There are also researchers that distinguished between the level of education needed to 'get' and to 'do' a job. Verhaest and Omey (2010) asked the question "what level of education necessary to get your job?" Meanwhile, Alba-Ramirez (1993) asked "what kind of education needed to do your job?" Both give different connotations regarding the level of education required to get and do a job. However, Green, Mclntosh and Vignoles (2002) found in most cases, there is no distinction between the two. According to them, the respondents are categorized as overeducated, undereducated and match based on the comparison between the actual education level and the education level required by the job. If their actual education level is higher (lower) than the level required, then the respondents are overeducated (undereducated). 
The third one is known as Realized Match. It is the least used method and only be used when there is no information regarding work or studied phenomenon (Battu, Belfield, \& Sloane, 2000). Determination of overeducation, undereducation and match are based on a comparison between respondents' actual education level against the mean (Verdugo and Verdugo, 1989) or mode (Kiker, Santos and De Oliveira, 1997) value, which calculated for the required education level. For those who use mean, respondents are said to be overeducated (undereducated) if their actual education level exceeds (less) than one standard deviation of certain occupational classification mean (Verhaest \& Omey, 2010).

An individual which their education level is within plus and minus this standard deviation is assumed to be in a perfect match. The same goes to the calculation using mode where overeducation (undereducation) occurs when actual education is higher (lower) from the value of calculated mode for the certain occupational group. Meanwhile, matches happen when the mode value is the same as the level of education attained. Although each of these methods has its own advantages and disadvantages, it is still widely used to measure overeducation.

\section{DATA, METHODOLOGY AND RESULT}

\subsection{Data and Methodology}

The annual data of graduates classified by highest certificate and occupation were obtained from the Graduate Tracer Study published by the Ministry of Education Malaysia from 2012 to 2017. In this paper, graduates have been separated to degree and diploma holders where these level of studies contributed to a large percentage of total graduates produced by the university. This data was calculated and analysed descriptively using figures and tables. In contrast to the Self-Perceived method of measurement, which is often used to analyse the issue of overeducation in Malaysia, this paper, however, employs a Job Analyst Method in investigating the extent of overeducation. As mentioned in section 2.2, this method measures the level of education needed to perform certain occupation based on the classification of work determined by the job expert in the International Standard Classification of Occupation (ISCO) (as in Table 1).

For the Malaysian case, this classification is based on the Malaysia Standard Classification of Occupations (MASCO) ${ }^{1} 2013$ where job classification is the same as ISCO. Based on Table 1, there are ten major categories of occupation which are classified by skill and education levels. For the purpose of this paper, we use the classification of occupation at the 1-digit level (major group). In the table, the first three highest groups of occupation require a non-manual high-skilled or tertiary education level qualification. Meanwhile, occupations group (4) to (8) require secondary education qualification and group (9) is for the unskilled and primary education level. For the group of occupation 10 (armed forces), it is not bound to the education level. Thus, this group is excluded from the match and non-match since the level of education required for this job is not specifically determined. Graduates are classified as a match when their education level attained equal to the education level needed in the occupation group. In this case, they match when they are in a group of occupation (1) to (3) and otherwise, if they are in the classification of occupation (4) - (9). In other words, major group of (1) legislators, senior officials and managers, (2) professionals and (3) technicians and associate professionals are wellmatched groups to the graduates' qualification.

\footnotetext{
${ }^{1} \mathrm{MASCO}$ - National benchmark for the classification of occupations in the employment structure of Malaysia.
} 
Table 1. Dictionary of Occupational Titles (DOT) in the International Standard Classification of Occupation (ISCO)

\begin{tabular}{|c|c|c|}
\hline ISCO Major Group & Broad Occupation Group & Skill Level \\
\hline $\begin{array}{l}\text { 1. Legislators, senior officials, managers } \\
\text { 2. Professionals } \\
\text { 3.Technicians and Associate Professionals }\end{array}$ & High-skilled non-manual & $\begin{array}{l}\text { Tertiary } \\
\text { (ISCED 5-6) }\end{array}$ \\
\hline $\begin{array}{l}\text { 4. Clerks } \\
\text { 5. Service workers, shop, market sales workers }\end{array}$ & Low-skilled non-manual & $\begin{array}{l}\text { Secondary } \\
\text { (ISCED 3-4) }\end{array}$ \\
\hline $\begin{array}{l}\text { 6. Skilled agricultural and fishery workers } \\
\text { 7. Craft and related trades workers } \\
\text { 8. Plant and machine operators and assemblers }\end{array}$ & Skilled manual & \\
\hline 9. Elementary occupations & Unskilled & $\begin{array}{l}\text { Primary } \\
\text { (ISCED 1-2) }\end{array}$ \\
\hline 0. Armed forces & Not bound to education level & \\
\hline
\end{tabular}

\subsection{Result}

From the result, it should be first noted that the percentage of overeducation in Malaysia had increased either for the degree or diploma holders. However, by the level of qualification attained, the highest proportion of overeducated was from diploma holders instead of degree holders (refer to Figure 1 and Figure 2). From 2012 to 2017, both figures showed the same trend for diploma and degree holders where the percentage for the nonmatched job had increased and decreased for the matched job respectively. The percentage of graduates in the classification of occupation (1) - (3) (matched) had decreased from 70 to 62 percent for degree holders and from 45.5 to 34.1 percent for diploma holders over the same year.

Meanwhile, the percentage for the non-matched occupation was in the classification of occupation (4) - (9) had increased from 30 percent to 37 percent for degree holders, and 54.5 percent 65.5 percent for diploma holders. Indirectly, this situation indicates that Malaysian graduates are accepting jobs that require a lower level of qualification than their actual level of educational attainment or in other words, graduates possibly accepted lower jobs for an income rather than waiting for jobs that matched their qualifications.

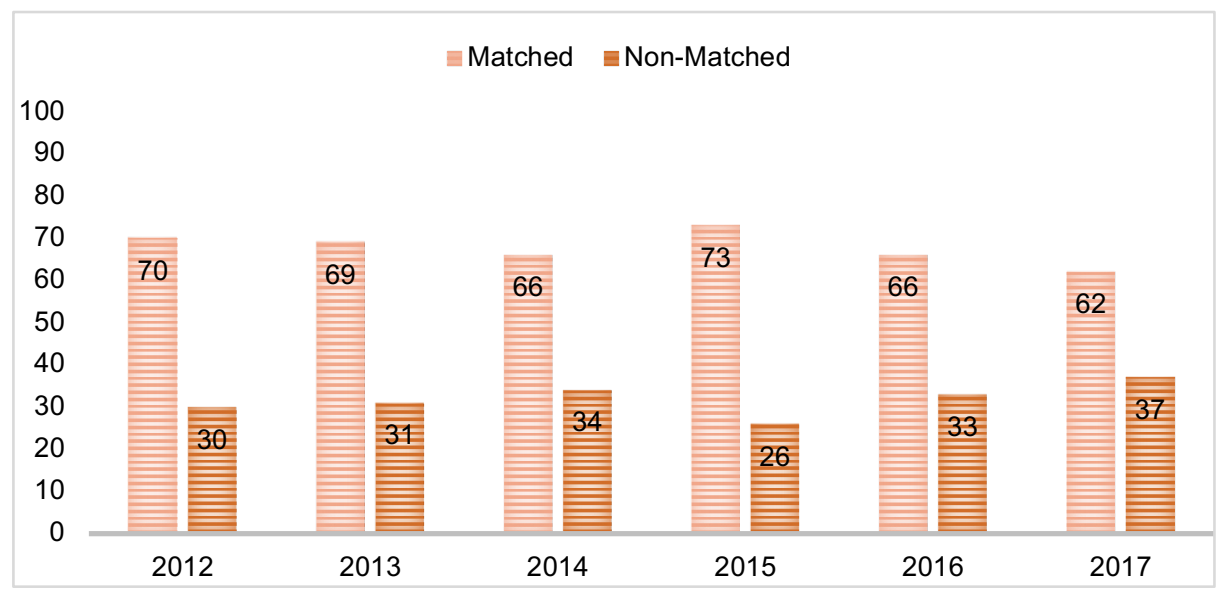

Figure 1. Percentage Distribution of Employed Degree Graduates in Matched and Non-Matched Occupation in Malaysia, $2012-2017$.

Source: Calculated from 2012 - 2017 Graduate Tracer Study data Note: This calculation is based on the Dictionary of Occupational Titles as in Table 1. 


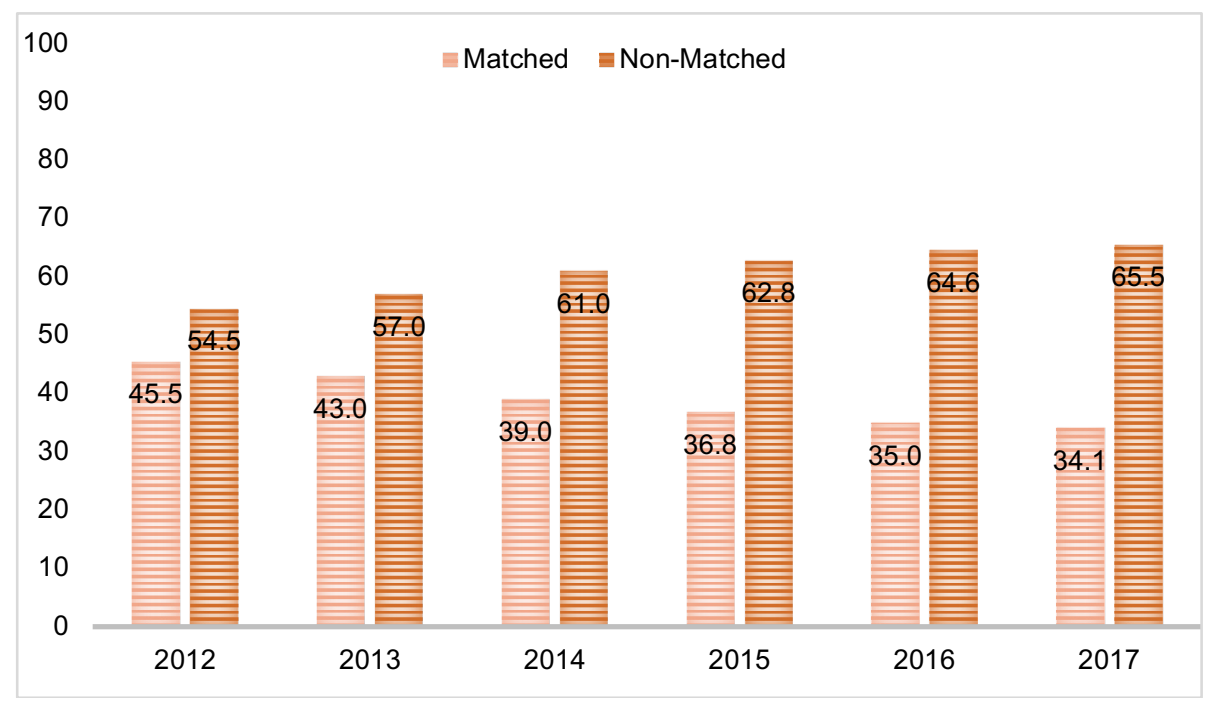

Figure 2. Percentage Distribution of Employed Diploma Graduates in Matched and Non-Matched Occupation in Malaysia, $2013-2017$

Source: Calculated from 2012 - 2017 Graduate Tracer Study data Note: This calculation is based on the Dictionary of Occupational Titles as in Table 1.

A detailed observation into the non-matched classification of occupations shows that the highest percentage of degree and diploma graduates worked as clerks. From the year 2012 to 2017, the percentage of degree holders worked as clerks had increased from 15 to 17.6 percent, while diploma holders had decreased slightly from 24.1 to 21.5 percent (refer to Table 2). As we are aware, this position does not require a tertiary level qualification. This group contributes around $13-25$ percent of the total overeducated in the year 2012 to 2017 . This followed by service and sales worker category, which contributes around 9 - 25 percent of the total overeducated. More surprisingly, the thirdhighest percentage is from the elementary occupation, which only requires primary level qualification to obtain jobs. This category reported a figure of between $3-10$ percent of the total overeducated degree and diploma holders (group work 9).

Table 2. Percentage of Employed Graduates in Non-Graduates Occupation, Malaysia, 2012 -

\begin{tabular}{lcccccc}
\hline Category of Occupation/Year & \multicolumn{3}{c}{2017} & Degree (\%) & \multicolumn{3}{c}{ Diploma (\%) } \\
\cline { 2 - 7 } & $\mathbf{2 0 1 2}$ & $\mathbf{2 0 1 5}$ & $\mathbf{2 0 1 7}$ & $\mathbf{2 0 1 2}$ & $\mathbf{2 0 1 5}$ & $\mathbf{2 0 1 7}$ \\
\hline Clerks & 15.0 & 13.0 & 17.6 & 24.1 & 24.7 & 21.5 \\
\hline Service workers, shop, market sales workers & 9.9 & 8.9 & 12.9 & 17.4 & 21.2 & 24.5 \\
\hline Skilled agricultural and fishery workers & 0.4 & 0.4 & 0.4 & 0.6 & 0.7 & 0.8 \\
\hline Craft and related trades workers & 1.0 & 1.0 & 1.4 & 3.6 & 5.0 & 5.6 \\
\hline Plant and machine operators and assemblers & 0.3 & 0.3 & 0.6 & 1.3 & 1.4 & 2.9 \\
\hline Elementary occupations & 3.0 & 2.8 & 3.8 & 7.5 & 9.8 & 10.2 \\
\hline Source: $2012-2017$ Graduate Tracer Study by MOE & & & & & &
\end{tabular}

The study by Zainizam (2017) using a Graduate Tracer Study dataset in 2007, employed a subjective measurement of overeducation in which it relies on worker's assessment. The findings showed that approximately 32 percent of workers were mismatched and 52 percent were actively searching for another job. Through the same method of measurement, it was found that the total graduates who were in this non-graduate job in Malaysia contributed around 30 to 41 percent or one-third of the employed graduate (Ishak, Rahmah \& Robiah, 2008; Lim, 2013; Zainizam \& Battu, 2013). In comparison, 
using a Job Analyst Method of measurement as this study shows, the extent of overeducation for degree holders is around 26 to 37 percent which is slightly lower than the results obtained through the subjective method that was used in the previous Malaysian literature.

\section{CONCLUSION}

The expansion of higher education in Malaysia had raised the possibility of overeducation, particularly if this increase in the supply of highly educated labour is not met by an increase in its demand. As far as the issue concerning the vertical mismatch or overeducation is concerned, it has long been discussed in developed countries, but still, receive less attention in developing countries such as Malaysia. Based on some empirical studies on overeducation in Malaysia, the issue is nevertheless crucial and need to be properly addressed in particular where this phenomenon seems to be persistent and affecting the career development of graduates. Realizing that studies in this area are quite scarce, in this paper, we examine the extent of overeducation among graduates in Malaysia labour market using a Job Analyst Method which is one of the well-known methods in measuring overeducation.

From the descriptive analysis, we found that the number of overeducated graduates in Malaysia labour market is increasing based on the period under study. The largest proportion is from diploma holders and for both qualification levels (degree and diploma), the majority of graduates are in job classification (4) and (5), i.e. clerk and sales workers. It is interesting to note that, even if the extent of overeducation measured through a Job Analyst Method is lower compared to the previous studies, the figure $26-37$ percent is considered high for a country like Malaysia with a vision of moving towards a digitalized economy. In a nutshell, it demonstrates either the failure of the higher education system to produce graduates as required by the market which related to the quality of education or the inability of the market to absorb the surplus of graduates in the labour market which implies a failure in human capital planning. Both, if not properly addressed, will result in economic, political and social discontent. Since the government has spent a huge sum of money for investment in human capital, particularly in higher education, appropriate action should be initiated to address issues related to overeducation in Malaysia.

\section{REFERENCES}

Abbas, Q. (2008). Over-education and under-education and their effects on Earnings: Evidence from Pakistan, 1998-2004. SAARC Journal on Human Resource Development, 109-125.

Alba-Ramirez, A. (1993). Mismatch in the Spanish labor market. Overeducation? The Journal of Human Resources, 28(2), 259-278.

Allen, J., \& De Weert, E. (2007). What do educational mismatches tell us about mismatches? A cross country analysis. European Journal of Education, 42(1), 59-73.

Allen, J., \& Van der Velden, R. (2001). Educational mismatches versus skill mismatches: effects on wages, job satisfaction, and on-the-job search. Oxford Economic Papers, 3, 434-452.

Barcena-Martin, E., Budria, S., \& Egido, A. (2011). Skill mismatches and wages among European university graduates. (MRPA Paper No. 33673, 2011). Retrieved from http://mpra.ub.uni-muenchen.de/33673/

Battu, H., Belfield, C., \& Sloane, P. (2000). How well can we measure graduate overeducation and its effects? National Institute Economic Review, 171, 82-93.

Boll, C., Leppin, J. S. \& Schömann, K. (2016). Who is overeducated and why? Probit and dynamic mixed multinomial logit analyses of vertical mismatch in East and West Germany, Education Economics, 24, (6), 639-662. Retrieved from http://dx.doi.org/10.1080/09645292.2016.1158787.

Boudarbat, B., \& Chernoff, V. (2012). Education-job match among recent Canadian university graduates. Applied Economics Letters, 19(18), 1923-1926.

Bu"chel, F., \& Pollmann-Schult, M. (2004). Overeducation and human capital endowments. International Journal of Manpower, 25(2), 150-166. 
Bla'zquez, M., \& Budri'a, S. (2012). Overeducation dynamics and personality, Education Economics, 20(3), 260-283.

Blenkinsopp, J., \& Scurry, T. (2011). Under-employment among recent graduates: a review of the literature. Personnel Review, 40(5), 643-659.

Department of Labour Peninsular Malaysia. (2013). Malaysia Standard Classification of Occupations (MASCO) 2013. Ministry of Human Resources. Retrieved from jtksm.mohr.gov.my/en/sumbersumber/penerbitan/garis-panduan/814-malaysia-standard-classification-of-occupations-masco-2013.

Farooq, S. (2011). Mismatch between education and occupation : A case study of Pakistani graduates. The Pakistan Development Review, 50(4).

Feldman, D. C. (1996). The nature, antecedents and consequences of underemployment. Journal of Management, 22, 385-407.

Figueiredo, H., Biscaia, R., Rocha, V. \& Teixeira, P. (2017). Should we start worrying? Mass higher education, skill demand and the increasingly complex landscape of young graduates' employment. Studies in Higher Education, 42(8), 1401-1420. Retrieved from https://doi.org/10.1080/03075079.2015.1101754

Frei, C., \& Sousa-Poza, A. (2012). Overqualification: permanent or transitory? Applied Economics, 44(14), $1837-1847$.

Frenette, M. (2004). The overqualified Canadian graduate: the role of the academic program in the incidence, persistence, and economic returns to overqualification. Economics of Education Review, 23(1), 29-45.

Friedland, D. S., \& Price, R. H. (2003). Underemployment: consequences for the health and well-being of workers. American Journal of Community Psychology, 32(1-2), 33-45. Retrieved from http://www.ncbi.nlm.nih.gov/pubmed/14570433

Gajderowicz, T., Grotkowska, G., \& Wincenciak, L. (2014). Graduates' job satisfaction across domains of study. International Journal of Manpower, 35(4), 470-499.

Garcia-Espejo, I., \& Ibanez, M. (2006). Educational-skill mismatches and labor market achievements among graduates in Spain. European Sociological Review, 22(2), 141-156.

Green, F., Mclntosh, S., \& Vignoles, A. (2002). The utilization of education and skills: Evidence from Britain. The Manchester School, 70(6), 792-811.

Groot, W., \& Maassen van den Brink, H. (2000). Skill mismatches in the Dutch labor market. International Journal of Manpower, 21(8), 584-596.

Halaby, C. (1994). Overeducation and skill mismatch. Sociology of Education, 67(1), 47-59.

International Labor Organization. (2013). Global Employment Trends for Youth 2013 | A generation at risk. Retrieved from http://www.ilo.org/global/research/global-reports/global-employment-trends/ youth/2013/lang-en/index.htm

Ishak Yussof, Rahmah Ismail \& Robiah Sidin. (2008). Graduan dan alam pekerjaan: Kes siswazah UKM. Akademika, 72, 3-24.

Kementerian Pendidikan Malaysia. (2019). Kajian Pengesanan Graduan 2012. Retrieved from http://www.mohe.gov.my

Kementerian Pendidikan Malaysia. (2019). Kajian Pengesanan Graduan 2013. Retrieved from http://www.mohe.gov.my

Kementerian Pendidikan Malaysia. (2019). Kajian Pengesanan Graduan 2014. Retrieved from http://www.mohe.gov.my

Kementerian Pendidikan Malaysia. (2019). Kajian Pengesanan Graduan 2015. Retrieved from http://www.mohe.gov.my

Kementerian Pendidikan Malaysia. (2019). Kajian Pengesanan Graduan 2016. Retrieved from http://www.mohe.gov.my

Kementerian Pendidikan Malaysia. (2019). Kajian Pengesanan Graduan 2017. Retrieved from http://www.mohe.gov.my

Kiker, B. F., Santos, M. C., \& De Oliveira, M. (1997). Overeducation and undereducation: Evidence for Portugal. Economics of Education Review, 16(2), 111-125.

Kucel, A. (2011). Ensayo bibliográfico: Literature Survey of the Incidence of Over-education: A Sociological Approach, Reis, 134, 125-142. Retrieved from http://reis.cis.es/REIS/PDF/Reis_134_061302519925436.pdf

Li, F., Morgan, W. J., \& Ding, X. (2008). The expansion of higher education, employment and over-education in China. International Journal of Educational Development, 28(6), 687-697.

Lim, H. E. (2013). Overeducation and happiness in the Malaysian graduate labour market. International Journal of Business and Society, 14(1), 93-110.

Linsley, I. (2005). Causes of overeducation in the Australian labor market. Australian Journal of Labour Economics, 8(2), 121 - 143.

McGuiness, S. (2003). Graduate overeducation as a sheepskin effect: evidence from Northern Ireland. Applied Economics, 35, 597-608.

McKee-Ryan, F. M., \& Harvey, J. (2011). "I Have a Job, But . . .": A Review of Underemployment. Journal of Management, 37(4), 962-996. 
Mehta, A., Felipe, J., Quising, P., \& Camingue, S. (2011). Overeducation in developing economies: How can we test for it, and what does it mean? Economics of Education Review, 30(6), 1334- 1347.

Ortiz, L. (2010). Not the right job, but a secure one: over-education and temporary employment in France, Italy and Spain. Work, Employment \& Society, 24(1), 47-64.

Piper, A. (2015). Heaven knows I'm miserable now: overeducation and reduced life satisfaction. Education Economics, 23(6), 677-692, http://dx.doi.org/10.1080/09645292.2013.870981

Quinn, M. A., \& Rubb, S. (2006). Mexico's labor market: The importance of education-occupation matching on wages and productivity in developing countries. Economics of Education Review, 25(2), 147-156

Rahona-López, M., \& Pérez-Esparrells, C. (2013). Educational attainment and educational mismatch in the first employment in Spain. Hindawi Publishing Corporation ISRN Education.

Robert, P. (2014). Job mismatch in early career of graduates under post-communism. International Journal of Manpower, 35(4), 500-513.

Robst, J. (2007). Education and job match: The relatedness of college major and work. Economics of Education Review, 26(4), 397-407.

Robst, J. (2008). Overeducation and college major: Expanding the definition of mismatch between schooling and jobs. Manchester School, 76(4), 349-368.

Rubb, S. (2014). Factors influencing the likelihood of overeducation: A bivariate probit with sample selection framework. Education Economics, 22(2), 181-208.

Sicherman, N. (1991). "Overeducation" in the labor market. Journal of Labor Economics, 9(2), 101-122.

Sloane, P. J. (2007). Policy forum: Education and skill mismatches in the labour market. Overeducation in the United Kingdom. The Australian Economic Review, 40(3), 286-291.

Statistik Pendidikan Tinggi. (2018). Kementerian Pendidikan Malaysia. Retrieved from https://www.moe.gov.my/muat-turun/laporan-dan-statistik/pendidikan-tinggi/buku-perangkaan/201810Statistik Pendidikan Tinggi.

Statistik Pendidikan Tinggi. (2003). Kementerian Pendidikan Malaysia. Retrieved from https://www.moe.gov.my/muat-turun/laporan-dan-statistik/pendidikan-tinggi/buku-perangkaan/201810Statistik Pendidikan Tinggi.

Summerfield, F. \& Theodossiou, I. (2017). The Effects of Macroeconomic Conditions At Graduation on Overeducation. Economic Inquiry, 55(3), 1370-1387, https://doi.org/10.1111/ecin.12446.

Tarvid, A. (2013). Unobserved Heterogeneity in Overeducation Models: Is Personality More Important than Ability? Procedia Economics and Finance, 5, 722-731. International Conference On Applied Economics (ICOAE) 2013.

Vaisey, S. (2006). Education and its discontents: Overqualification in America, 1972-2002. Social Forces, 85(2), 835-864.

Verdugo, R. R., \& Verdugo, N. T. (1989). The impact of surplus schooling on earnings: Some additional findings. The Journal of Human Resources, 24(4), 629-643.

Verhaest, D., \& Omey, E. (2010). The determinants of overeducation: different measures, different outcomes? International Journal of Manpower, 31(6), 608-625.

Voon, D., \& Miller, P. W. (2005). Undereducation and overeducation in the Australian labour market. The Economic Record, 81(255), S22-S33.

Wald, S. (2005). The impact of overqualification on job search. International Journal of Manpower, 26(2), 140156.

Wolbers, M. H. J. (2003). Job mismatches and their labour-market effects among school-leavers in Europe. European Sociological Review, 19(3), 249-266.

Worldbank. (n.d.). Worldbank Databank. Retrieved from http://databank.worldbank.org/data/home.aspx.

Yang, J., \& Mayston, D. (2012). Impact of overeducation on wages in China. The Chinese Economy, 45(2), $65-89$.

Zainizam Zakariya (2017). Job Mismatch and On-the-job Search Behavior Among University Graduates in Malaysia. Asian Economic Journal, 31(4), 355-379.

Zainizam Zakariya (2014). Wage effects of over-education and mismatch in Malaysia: A random effect approach. Jurnal Ekonomi Malaysia, 48(2), 3-17.

Zainizam Zakariya. (2013). Returns to education: What does over-education play? The Malaysian National Economic Conference (PERKEM) VIII (pp. 266-278). Kuantan, Pahang.

Zainizam Zakarya. (2012). Overeducation and overskilling in Malaysia. Unpublished Ph.D Thesis. University of Aberdeen.

Zainizam Zakariya \& Battu, H. (2013). The effects of overeducation on multiple job satisfaction towards enhancing individuals' well-being in Malaysia. Business and Management Quarterly Review, 4(3\&4), 3851.

Zainizam Zakariya, Norimah Rambeli @ Ramli, Normala Zulkiflee \& Noor Fazlin Mohamed Noor (2014). Overeducation and under-education in Malaysia: Does ethnicity matter? Proceeding of the Social Sciences Research ICSSR (e-ISBN 978-967-11768-7-0), (pp. 498-516). Kota Kinabalu, Sabah. 
Job Mismatch and Overeducation among Graduates in Malaysia

Zulkifli Osman \& Hazrul Izwan Shahiri. (2013). Ketaksepadanan Pekerjaan dan Inflasi Pendidikan. Jurnal Ekonomi Malaysia, 47(2), 137-147. 